\title{
Neuropathic pain after a dental procedure in an older adult with Alzheimer's disease: a case report
}

\author{
Dor neuropática em idoso com doença de Alzheimer \\ após procedimento odontológico: relato de caso
}

\author{
Erica Negrini LIA ${ }^{1}$ iD https://orcid.org/0000-0001-5691-415X \\ Marco Polo Dias FREITAS ${ }^{2}$ iD https://orcid.org/0000-0002-2310-3681 \\ Lucas Fernando TABATA ${ }^{1}$ iD https://orcid.org/0000-0002-3470-5290 \\ Fabiano MALUF ${ }^{3}$ iD https://orcid.org/0000-0002-3395-069X \\ Sergio Bruzadelli MACEDO ${ }^{1}$ iD https://orcid.org/0000-0002-5417-4239
}

\section{ABSTRACT}

Neuropathic pain occurs when there is damage to nervous system structures, particularly as a result of direct injury or disease. It can occur in the orofacial territory after dental implants placement. Oral rehabilitation is often performed with dental implant placement for older adults. However, the general health status should be considered, requiring a careful assessment of the patient and the identification of geriatric conditions that could lead to predictable failures. The purpose of this case report is to present the diagnosis and treatment of neuropathic pain after dental implant placement in an older adult with dementia due to Alzheimer's disease.

Indexing terms: Alzheimer's disease. Facial pain. Elderly. Dental implants.

\section{RESUMO}

A dor neuropática ocorre quando há dano às estruturas do sistema nervoso, particularmente como resultado de injúria direta ou doença. Pode ocorrer no território orofacial após colocação de implantes dentários. A reabilitação oral é frequentemente realizada por meio da colocação de implantes dentários em pessoas idosas. Entretanto, o estado de saúde geral deve ser considerado, o que requer avaliação cuidadosa do paciente e identificação de condições geriátricas que podem levar a falhas previstas. O objetivo do relato desse caso clínico é apresentar o diagnóstico e o tratamento da dor neuropática após colocação de implante dentário em um idoso com demência em função de doença de Alzheimer.

Termos de indexação: Doença de Alzheimer. Dor facial. Idoso. Implantes dentários.

\footnotetext{
$\boldsymbol{\nabla} \boldsymbol{\nabla} \boldsymbol{v}$
}

1 Universidade de Brasília, Faculdade de Ciências da Saúde, Departamento de Odontologia, Campus Universitário Darcy Ribeiro, Asa Norte, 70910-900, Brasília, DF, Brasil. Correspondence to: EN Lia. E-mail: <ericalia@unb.br>.

${ }^{2}$ Centro Multidisciplinar do Idoso, Hospital Universitário de Brasília. Brasília, DF, Brasil.

${ }^{3}$ Centro Universitário Euroamericano (UNIEURO). Brasília, DF, Brasil.

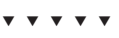

Lia EN, Freitas MPD, Tabata LF, Maluf F, Macedo SB. Neuropathic pain after a dental procedure in an older adult with Alzheimer's disease: a case report. RGO, Rev Gaúch Odontol. 2021;69:e20210024. http://dx.doi.org/10.1590/1981-86372021002420190137 


\section{INTRODUCTION}

Neuropathic pain occurs when there is damage to nervous system structures, particularly as a result of direct injury or disease [1]. The neuroanatomical distribution of pain can be perceived on physical examination; however, an underlying tissue injury cannot always be found [1]. Paresthesia and neuropathic pain may occur after some dental surgeries, such as dental implant placement, in spite of high success rates reported in the scientific literature [2].

Given the high rates of edentulism among older adults in Brazil, oral rehabilitation is often performed with dental implant placement for patients who have access to a private clinic [3]. However, age is a risk factor for several diseases, including dementia. Population aging is a reality all over the world, including developing countries in Latin America [4]; therefore, older adults who seek dental care, particularly oral rehabilitation, should have their general health status carefully assessed before treatment planning [5].

The purpose of this case report is to present the diagnosis and treatment of neuropathic pain after dental implant placement in an older adult with dementia due to Alzheimer's disease.

\section{CASE REPORT}

J.H., 86 years old, retired gardener, diagnosed with dementia caused by late-stage Alzheimer's disease, was assessed by the healthcare team at the Multidisciplinary Center for Older Adults at Universitary Hospital of Brasília in 2014. At the time, the patient presented with almost total dependency for all activities of daily living, double incontinence, dysphagia, crying out (groaning), frequent episodes of psychomotor agitation, insomnia, and intense pain in the mouth.

According to the clinical history, the patient started presenting with symptoms suggestive of dementia in 2003. Episodes of delusion ("the mouth was melting") and intense pain started after dental implant placement in the mandible in a private clinic in 2005. The patient's family stated that they sought dental care "to try to improve his masticatory function." Dental implant placement was planned and performed in the mandible for later attachment of a bar-clip retained overdenture. Additionally, a conventional maxillary complete denture was fabricated. However, the patient stopped wearing the maxillary denture and his continuous pain persisted, followed by unremitting left-sided peripheral facial palsy. Consequently, the denture was not placed in the mandible and the dental treatment was discontinued.

Extraoral examination showed the characteristic facial expressions of pain and left-sided facial palsy with lip ptosis and lip ulcer (figure 1). Intraoral examination showed two exposed healing abutments with visible biofilm build-up around them and associated moderate gingival inflammation (figure 2). Computed tomography images showed extensive alveolar ridge resorption resulting from the patient's long-term edentulism and mandibular implants close to the mental foramen (figure 3).

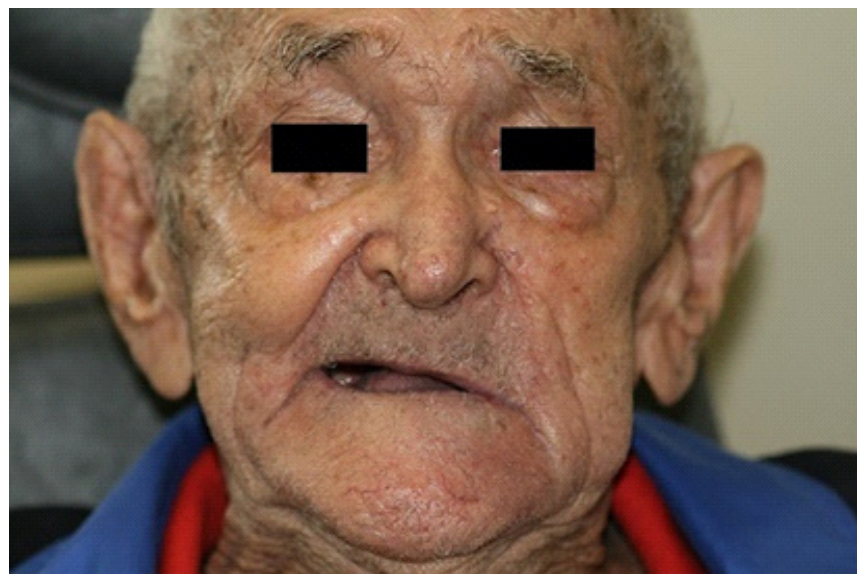

Figure 1. Facial expression of pain and left-sided facial palsy with lip ptosis and lip ulcer.

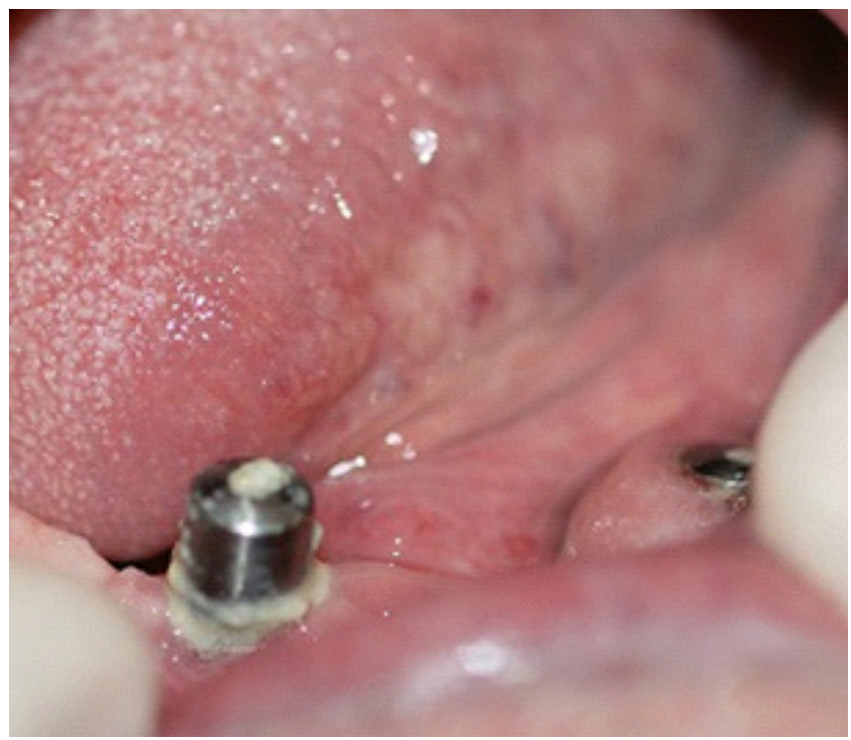

Figure 2. Exposed healing abutments. 

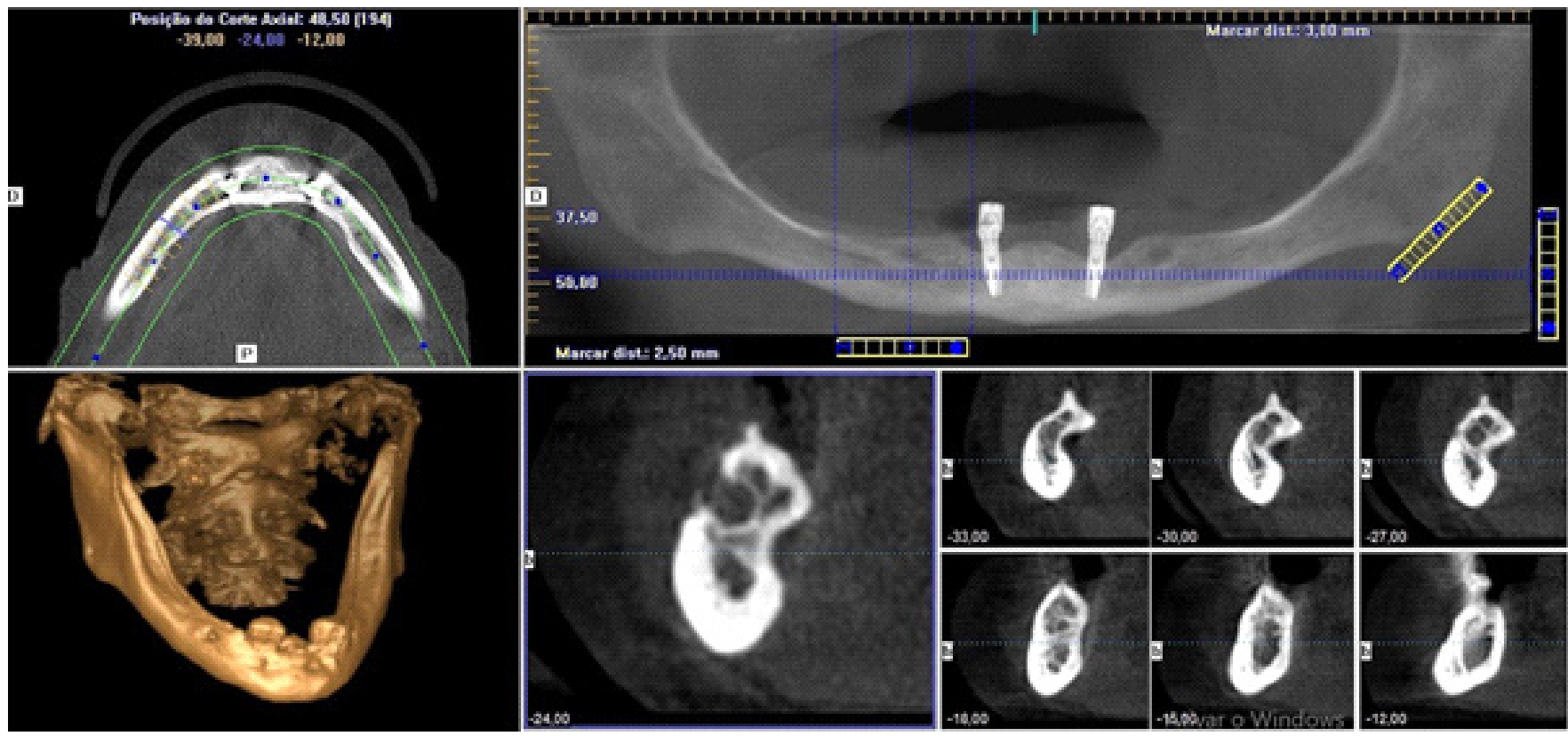

Figure 3. Mandible computed tomography with magnification of the right mental foramen.

Management included administration of gabapentin on a titration schedule, with a starting dose of $300 \mathrm{mg}$ in the morning in the first week, $600 \mathrm{mg}$ (divided into 2 doses) in the second week, and $900 \mathrm{mg}$ (divided into 3 doses) in the third week. Additionally, a bilateral mental nerve block was performed and a trigger area was found on the right side.

Considering the patient's general health status, the implants could not be surgically removed and therefore a right-side mental nerve neurolysis was performed. The lip ulcer was treated with dexpanthenol ointment.

After these treatments, the patient stopped groaning and started sleeping better. The patient was followed weekly until he improved in the third week after treatment. Thereafter, monthly follow-up visits were scheduled. The patient died in April 2015, at 87 years.

\section{DISCUSSION}

Pain assessment in a patient with dementia is challenging owing to difficulties in communication and in the proper interpretation of signs. Neuropathic pain is commonly described as "pins and needles," "burning," "stinging," and "electrical shock" and occurs after the repetition or removal of the stimulus which may not even be harmful, characterizing allodynia [6]. Positive symptoms like paresthesia and hyperesthesia, and negative symptoms like hypoesthesia can be present [7]. However, it is difficult to obtain information through medical history and physical examination in patients with moderate to severe dementia. Therefore, behavioral changes, facial expressions of pain, crying, groaning, and delirium [8] should be evaluated. Several of these signs and symptoms were found in the case reported herein.

Physiological changes, functional limitations, and multiple health conditions, including dementia due to Alzheimer's disease, are more prevalent in aging populations [4,9], causing significant impacts on oral health and requiring adjustments in dental treatment. Dementia due to Alzheimer's disease is characterized by slow and progressive memory impairment and other cognitive changes, such as spatial and temporal disorientation; language impairment, both in expression and comprehension; poor judgment; changes in praxis (performance of previously learned motor acts); and agnosia (partial or total recognition difficulty). These changes occur over time and are not uniform, impairing the individuals' functional capacity, making them increasingly dependent on other people to perform daily activities [9].

In the case presented here, gabapentin treatment in association with mental nerve neurolysis was efficient, relieving the patient's pain and suffering, supporting the diagnostic hypothesis of neuropathic pain. Gabapentin is an alpha-2-delta calcium channel ligand anticonvulsant considered one of the first-line drugs for the treatment 
of neuropathic pain [10]. The advantage of administering gabapentin to older patients is its safety profile since it does not interfere with hepatic microsomal enzymes and has a low rate of drug interactions [11]. The most common adverse effects include nausea, vomiting, sleepiness, and dizziness, which can be managed with titration to the analgesic dose. A reduction in glomerular filtration rate, which is not infrequent in older people, requires gabapentin dose adjustment because of its exclusive renal clearance [12].

There are few literature reports on neuropathic pain in patients after dental implant placement and a clear cause or lesion could not always be found in the reported cases [7]. A retrospective cohort study conducted at the University of Barcelona found a $0.5 \%$ prevalence of trigeminal neuralgia after dental implant placement, which is a rather low rate, thus showing that the procedure is safe [2].

Old age is not a contraindication for dental implant placement. However, the general health status should be considered, requiring a careful assessment of the patient and the identification of geriatric conditions that could lead to predictable failures [2]. The most adequate treatment plan is not always the one that is technically feasible, but rather the one that meets the individual needs of an older person. Therefore, it is critical to identify the patient's stage of dementia and the prognosis to try to avoid invasive procedures and often seek palliative care as a favorable option to maintain oral health.

\section{CONCLUSION}

Although oral rehabilitation with dental implants is safe, it is extremely important to consider the patient's general health status before proposing any treatment. Treatment success and failure and its advantages and disadvantages should be discussed with the family and professional caregivers of the older adult with dementia. In the case described here, a multidisciplinary effort was essential to establish the diagnosis and relieve the patient's pain and suffering.

\section{Collaborators}

EN LIA performed the patient's oral exam and wrote the manuscript. MPD FREITAS was responsible for medical treatment and revised the manuscript. LF TABATA assessed dental implants, performed the images, and revised the manuscript. F MALUF was responsible for ethical assessment and revised the manuscript. SB MACEDO performed dental treatment and revised the manuscript.

\section{REFERENCES}

1. Treede RD, Jensen TS, Campbell JN, Cruccu G, Dostrovsky JO, Griffin JW, et al. Neuropathic pain: redefinition and a grading system for clinical and research purposes. Neurology. 2008;70(18):1630-5. https://doi.org/10.1212/01. wnl.0000282763.29778.59

2. Vázquez-Delgado $E$, Viaplana-Gutiérrez $M$, Figueiredo $R$, Renton T, Gay-Escoda C, Valmaseda-Castellón E. Prevalence of neuropathic pain and sensory alterations after dental implant placement in a university-based oral surgery department: A retrospective cohort study. Gerodontology. 2018;35(2):117-122. https://doi.org/10.1111/ger.12326

3. Brasil. Ministério da Saúde. Secretaria de atenção à saúde. Secretaria de vigilância em saúde. Departamento de atenção básica. Coordenação geral de saúde bucal. SB Brasil 2010 - Pesquisa nacional de saúde bucal: resultados principais. Brasília: Ministério da Saúde; 2011 [citado 2019 oct 10]. Disponível em: <http://bvsms.saude.gov.br/bvs/publicacoes/ pesquisa_nacional_saude_bucal.pdf $>$.

4. Parra MA, Baez S, Allegri R, Nitrini R, Lopera F, Slachevsky $A$, et al. Dementia in Latin America: assessing the present and envisioning the future. Neurology. 2018;90(5):222-31. https://doi.org/10.1212/WNL.0000000000004897

5. Nasri F. O envelhecimento populacional no Brasil. Einstein. 2008;6(supl1): S4-S6.

6. Magrinelli F, Zanette G, Tamburin S. Neuropathic pain: diagnosis and treatment. Pract Neurol. 2013;13(5):292-307. http://dx.doi.org/10.1136practneurol-2013-000536

7. Politis C, Agbaje J, Van Hevele J, Nicolielo L, De Laat A, Lambrichts I, et al. Report of neuropathic pain after dental implant placement: a case series. Int J Oral Maxillofac Implants. 2017;32(2):439-444. https://doi.org/10.11607/jomi.5241

8. Hsu KT, Shuman SK, Hamamoto DT, Hodges JS, Feldt KS. J Am Dent Assoc. 2007;138(7):963-9. https://doi.org/10.14219/ jada.archive.2007.0293

9. Lane CA, Hardy J, Schott JM. Alzheimer's disease. Eur J Neurol. 2018;25:59-70. https://doi.org/10.1111/ene.13439

10. Finnerup NB, Attal N, Haroutounian S, McNicol E, Baron R, Dworkin $\mathrm{RH}$, et al. Pharmacotherapy for neuropathic pain in adults: a systematic review and meta-analysis. Lancet Neurol. 2015;14(2):162-73. https://doi.org/10.1016/S14744422(14)70251-0

11. Kukkar A, Bali A, Singh N, Jaggi AS. Implications and mechanism of action of gabapentin in neuropathic pain. Arch Pharm Res. 2013;36(3):237-51. https://doi.org/10.1007/ s12272-013-0057-y

12. Shanthanna H, Gilron I, Rajarathinam M, AlAmri R, Kamath $S$, Thabane $L$, et al. Benefits and safety of gabapentinoids in chronic low back pain: A systematic review and meta-analysis of randomized controlled trials. PLoS Med. 2017;14(8):e1002369. https://doi.org/10.1371/journal.pmed.1002369

Received on: 5/10/2019

Final version resubmitted on: 12/2/2020

Approved on: 27/4/2020 